УДК $364: 316$

DOI: $10.24144 / 2524-0609.2021 .49 .20-23$

\author{
Bartosh Olena \\ Candidate of Pedagogical Sciences, PhD, Associate Professor \\ Department of Sociology and Social Work \\ State University «Uzhhorod National University», Uzhhorod, Ukraine \\ olena.bartosh@uzhnu.edu.ua \\ http://orcid.org/0000-0001-6733-5516
}

\title{
UNDERSTANDING THE RISK IN THE YOUTH ENVIRONMENT
}

\begin{abstract}
The formation of modern youth is taking place in the period of socio-political transformations, which directly impact the life orientations of young people, their behaviour, social-economic situation. The factors mtioned above contribute to the spread of risks associated with threats to health and life, uncertainty of life start and selfrealization, value and regulatory uncertainty. The purpose of the article: is to study approaches to identifying risk factors that impact the youth environment. Research methods applied: analysis and synthesis of scientific literature (to clarify the key concepts of the study), systematization (in order to identify existing scientific approaches to solving the problem), theoretical generalization (to formulate the final provisions and conclusions). If earlier scientific researches were mainly concentrated within the limits of natural-scientific and economic courses, now the allocation of a separate interdisciplinary direction - riskology is actual. The majority of young people experience the problem of life-start, which has a negative impact on the working career of young people, their family life and lifestyle and makes young people financially dependent on their parents. Globalization has had a significant impact on the development of the risk society. In the context of globalization, traditional social ties are being destroyed; young people avoid traditional restrictions, but at the same time lose a sense of reliability, stability, confidence in the future and feel anxious and afraid of the need to choose. Therefore, public policy should take into account all the factors that have a negative impact on the youth environment and help minimize the risks and form «socially healthy» youth.
\end{abstract}

Key words: factors; risk; social integration; student youth.

Introduction. Today's adolescents and youth form a quarter of the world's population. They are shaping social and economic development, challenging social norms and values, and building the foundation of the world's future. The beginning of the XXI century is marked by the aggravation of youth problems in different countries, among which Ukraine is no exception. Nowadays, Ukrainian youth is affected by: political and economic crisis in the country; unemployment; unresolved housing conditions; poor health; social disorders; economic and psychological dependence on parents; marital and family problems (high divorce rate, family conflicts); low birth rate; loss of ideals, social perspective, and life optimism.

The purpose of the article: is to study approaches to identifying risk factors that impact the youth environment.

Research methods: analysis and synthesis of scientific literature (to clarify the key concepts of the study), systematization (in order to identify existing scientific approaches to solving the problem), theoretical generalization (to formulate the final provisions and conclusions)

Literature review. Global changes put the world in the face of a new social reality that disputes all existing notions of society. Uncertainty of the new reality, instability of social processes, penetration of risk into all spheres of society determined the emergence of border areas, the study of which was possible only on the basis of interdisciplinary approaches.

Risk is closely linked to the history of social development and has always existed, so knowledge of risks is of high demand. Risk research has been conducted for a long time and constantly by the representatives of a significant number of sciences. Each of the sciences describes risk from its point of view, builds schemes, identifies patterns and connections, develops theory and proposes methods for managing and minimizing risk. If earlier scientific researches were mainly concentrated within the frames of natural-scientific and economic disciplines, nowadays the devision of a separate interdisciplinary direction - risk science - becomes topical.

Risk research includes but is not limited to: theoretical doctrines of the "risk society" of W. Beck [1], A. Giddens [2], and N. Luhmann [3]; "concept of social risk enhancement" after R. Kasperson's et al. [4]; "psychometric paradigms" of risk after P. Slovic, S. Lichtenstein and B. Fishhoff [5]; risk as a "special branch of social knowledge" after O. Renn [6]. Issues of risk science have also been studied by Ukrainian scholars. O.Ukrainska [7] speaks of V. Cheshko's "problem of risk character of modern science"; E. Golovakha's "models of spatial distribution of risks"; A. Stegnii's "institutionalization of environmental interests in the society of sociogenic risks".

Sociology of risk, as an interdisciplinary science, has become the subject of scientific interest of S. Nikitin and K. Feofanov [8], who prove, that:

- It is to function at the intersection of different social sciences and humanities, constantly referring to their material, synthesizing diverse data, mostly abstracting from the consideration of: (i) individual psychological processes with emphasis on an individual; (ii) political, economic, ethical, culturological and other processes with an emphasis on exclusively political or narrow-economic risk mechanisms.

- It is to study social communities (city, village, labor collective, industrial enterprise, family, etc.), as well as social-psychological, social-political foundations of displays of their activities.

O. Yanitskiy $[9$, p. $7-8]$ points to two basic areas of understanding risk in the science:

- Realistic - risk is defined as "the product of the probability of danger and the severity (scale) of its consequences". In this case, risk is seen as something objective, independent of social and cultural environment, recognizable, measurable and, therefore, to some extent predictable. The disadvantage of this approach is the inability to study the social and cultural aspects of risks and their impact on the security of an individual and society as a whole.

- Social-cultural - risk is seen as a social construct rooted in culture, social relations and social institutions 
of society. There are two approaches to this: (i) risk is seen as an "objectively existing danger" mediated by a social and cultural context; (ii) risk is a social construct, a product of historically and culturally determined interpretation.

\section{Results and Discussion} society:

O.Yanitskiy [9] defines risk factors in an unstable

1. Social-economic factor - conditioned by: destruction of industrial and scientific-technical potential of a country; strategic dependence of its activities on imports; lags from advanced countries; orientation of governmental programs on borrowings. The natural result of such a policy is: a sharp decline in living standards of the vast population majority, including young people; the strengthening of its economic, social and political stratification, rising social tensions.

2. Social-legal factor - associated with both imperfection and non-compliance with current legislation, as well as with the lack of a developed system of legal and social protection. As a result, there is a sharp contradiction between formal and real population rights in general and young people in particular.

3. Social-political factor - determined by the inconsistency of activity of government branches. The presence of unlimited presidential power, incompetent, often changing governments / parliament, and the lack of clear ideas on possible models of society's development make state policy unpredictable. The weakness of the adopted laws, the lack of unified legislation in the context of increasing separatism in the regions provide for favorable opportunities for power redistribution in favor of the bureaucracy, oligarchic and criminal circles.

Understanding the development patterns of the youth as a social group directly relats the defining of its role and place in the social reproduction it is a subject of.

C. Williams, V. Chuprov and J. Zubok [10] understand by reproduction the constant repetition, continuous renewal of the process of social production, called to ensure the development of society and its individual groups as a whole system. Depending on the nature of this process, it can be destructive (developmental delay), simple (repetition) and extended (recovery on an ever-increasing scale).

Accordingly, the social development of the youth can: have destructive forms (disintegration, social exclusion); become a continuation of social experience got by previous generations (simple reproduction); acquire the features of expanded reproduction by renewing living conditions and the system of social relations [11].

By engaging in social relations and identifying with them, the younger generation integrates into society. Reflecting the nature of the cyclical reproduction of the system of social relations, this process in social terms appears as a change of youth's place in the social structure, i.e. as a certain strategy of its social mobility. The positive orientation of the change of quantitative and qualitative characteristics of the youth, in the course of its formation as a subject of social reproduction, testifies to the social development of this social-demographic group [12].

However, in a risk society, as a rule, there are no clear ideas about development goals. The functioning of such a society becomes spontaneous, often uncontrolled by social institutions. There is a process of spontaneous integration in the youth environment, aimed at reproducing structures that hinder the natural historical social development. Consciously or unconsciously, many young people find themselves involved in this process, risking their careers, families, and stable life [13].
V. Chuprov et al. [14, p. 71] identify typical risk situations in the youth environment. This typology does not cover the whole variety of life situations with different risks produced. The basis for the selection of these situations are the cycles of youth as a subject of social reproduction. The typical risk situations in the youth environment are connected with:

1. Endangering health and life. These are the situations that threaten health and lives of young people. If society does not provide conditions for the physical development of a young person, for the protection of health and safety of life, there are real grounds for risk. In these situations, a young person is constantly at risk of: falling behind peers in the development; having chronic diseases; losing health or even life. The risk of negative demographic reproduction increases.

2. Uncertainty of life start. The lower the status attributed to young people, inherited from their parents, the more uncertain the opportunities for them to choose their life strategy. If for people from highstatus families the starting positions in education, work, in setting a family is a kind of springboard provided by the capabilities of parents, then for the others the equalization of life opportunities is determined either by personal abilities, hard work, entrepreneurship, or help from the state. In the absence of a purposeful social policy, necessary guarantees and well-thought-out social protection measures for these categories of young people, the risks become associated with inequality of starting positions and false start, the consequences of which can determine the entire life of a young person.

3. Uncertainty of opportunities for self-realization. Inclusion in social life is a process full of drama, accompanied by unrealized ambitions, unfulfilled hopes, and shattered plans. The reason is often not rooted in the lack of activity of young people, but is determined by many social factors. Determining one's social position, acquiring the appropriate status and social role, selfaffirmation in them, being socially conditioned, require active social support. In the absence or lack of such support, the socially stratified risks increase, become associated with limited opportunities for upward mobility, the risks of downward mobility and social exclusion of young people.

4. Value and regulatory uncertainty. Values and norms play a crucial role in the integration of any society, giving a lasting and irreversible character to social ties. The whole inner world of an individual is based on them. In a society of risk, with its uncertainty and unpredictability, there is a significant deformation of this mechanism. Traditional social values are devalued and supplanted by group ones, the system of institutional norms is destroyed, new values and norms are rejected. In these conditions, there appear situations of insanity, in which a young person loses usual orientation, sense of support, and touch with society. The risk of social disorientation, anomie, rupture with social institutions and society as a whole increases.

5. Uncertainty of identity. The process of integration of young people into society is not limited to their mechanical inclusion in social structures, but is accompanied by internal identification with them. This makes the process sustainable. Therefore, striving to stabilize and preserve its integrity, society is interested in reproducing the socially significant foundations of identity.

The types of social conflicts discussed above are specifically youth, i.e. the basis of their emergence are the characteristics of young people as an independent social-demographic group. This does not mean that it does not take part in other types of conflicts, as it is at the 
same time an integral part of various social groups in the social structure (professional, political, national-ethnic, etc.). In various forms, conflicts between the youth and society are characteristic of all social systems with a developed social structure.

Yu. Zubok [15] identifies the following main ways to localize risk in the process of social integration of the youth:

- Narrowing the boundaries of risk. The problem of risk localization in the youth environment is closely related to the possibility of realizing specifically youth conflicts. By implementing the conflict through integration, society stabilizes the situation and, therefore, minimizes the risk, localizes it. Thus, the probability of risk is reduced, the environment for conflict is narrowed.

- Risk individualization. The process of individualization itself can lead to an expansion of risk situations, increasing the likelihood of its dangerous consequences. Integration contributes to the individualization of risk, localizes it within individual groups or individuals. In a risk society, individualization results in the fragmentation of opportunities and experiences, which in the absence of social goals and development criteria supports the uncertainty of a young person's life path and status.

- Lowering the uncertainty threshold. Uncertainty, in turn, involves risk at all stages of self-determination. The uncertainty of modern risk society allows great freedom for young people to choose their life path. However, the fragmentation of usual links between individual experience and possibilities of its implementation, provided by the state, significantly increases the risk of a negative outcome in the situation of choice. The balance of subjective and objective components of risk is disturbed. For example, the emergence of new forms of education, alternative to the state ones, involves expanding the opportunities for young people to choose the most acceptable path for their studies. If we take into account, that paid alternative education gradually displaces free public education, and payment for it is not affordable to everyone, it becomes obvious how high is the risk threshold for young people to remain without education.

- Regulation of risk orientation. The process of social integration of young people into the risk society involves: (i) reducing uncertainty in the environment of its activity (objective component of risk); (ii) increasing behavioral willingness to make decisions based on the nature, scale and dynamics of this uncertainty (subjective component of risk). Thus, the localization of risk is achieved by lowering the uncertainty threshold. In a risk society, the role of natural factors grows. To some extent, spontaneous processes in the social development of young people can have a constructive beginning. Without them, the innovative function of the youth, which provides an expanded reproduction of society, cannot be fully realized. However, natural processes are associated with risk, with its unpredictable consequences.

- Social insurance of failure. The integration of young people into a risk society takes place in the context of weakening its dependence on social institutions. Reducing the influence of a family and a state on young people, on the one hand, expands their independence, on the other hand, increases the likelihood of risk and minimizes guarantees in cases of failure. Localization of risk in the process of youth integration is ensured by reducing the level of uncertainty in the environment of young people's activity, by expanding social risk insurance.

Conclusion. Consideration of aspects of modern approaches to the study of risk allows us to draw the following conclusions: "risk society" is actually a new paradigm of social development. Reforming society, its transition to modern one, involves the renewal of the entire system of social relations, as well as the modernization of productive forces and production relations. The process, connected with innovation in all society spheres, cannot be fully predicted. This means it involves a certain risk. Under normal conditions, society is a system that develops dynamically, constantly overcoming one after another stages of modernization. Therefore, risk in the society is a necessary component of social development. Risk society is a specific way of organizing social relations, interaction and relations of people in conditions of uncertainty, when the reproduction of living conditions, of physical and spiritual forces of an individual aquires not socially conditioned, but mostly random, probabilistic character.

\section{Список використаної літератури}

1. Beck U. Risk Society. Toward a New Modernity. London: Sage Publications, 1992. 260 p.

2. Giddens A. Fate, Risk and Security / In A.Giddens (Ed.). Modernity and Self-Identity: Self and Society in the Late Modern Age. Cambridge: Polity Press, 1991.246 p.

3. Luhmann N. Der Begriff Risiko / In N.Luhmann (Ed.). Soziologie des Risikos. Berlin; New York: Walter de Gruyter, 1991. $256 \mathrm{~s}$.

4. Kasperson J., Kasperson R., Pidgeon N., Slovic P. The Social Amplification of Risk: Assessing fifteen years of research and theory. In N.Pidgeon, R.Kasperson, P.Slovic (Eds.). The Social Amplification of Risk. Cambridge, United Kingdom: Cambridge University Press, 2003. 468 p.

5. Slovic P. Introduction and overview. In P.Slovic (Ed.). The Perception of Risk. London: Earthscan Publications Ltd., 2000. $511 \mathrm{p}$.

6. Ренн О. Три десятилетия исследования риска: достижения и новые горизонты. Вопросы анализа риска. 1999. Т.1. № 1. C.80-99.

7. Украинская О.А. Рискология: социально-философский подход к исследованию «общества рисков». Bicник ХНУ ім. В.Н.Каразіна. Серія: Теорія культури и філософія науки. 2012. Вип. 47. С.42-47.

8. Никитин С., Феофанов К. Социологическая теория риска: в поисках предмета. Социс. 1992. № 10. С.120-127.

9. Яницкий О.Н. Социология риска. M.: LVS, 2003. 192 с.

10.Williams C., Chuprov V., Zubok J. Youth, risk and russian modernity. Aldershot: Ashgate, 2003. 248 p.

11.Зубок Ю., Чупров В. Жизненные стратегии молодежи: реализация ожиданий и социальные настроения. Мониторинг общественного мнения: экономические и сочиальные изменения. 2020. № 3. 13-41.

12.Woodman D., \& Wyn J. Youth and generation: rethinking change and inequality in the lives of young people. Thousand Oaks, CA: Sage, 2015. 201 p.

13.Bartosh O. Social risks for the youth in the dynamics of Ukrainian society / In N.Varha, B.Hvozdetska (Eds.), Challenges and opportunities of the modern risk society: socio-cultural, economic and legal aspects. Praha, Czech Republic: OKTAN PRINT, 2021. P.77-93.

14.Чупров В.И., Зубок Ю.А., Вильямс К. Молодежь в обществе риска. Москва: Наука, 2003. 161 с.

15.Зубок Ю.А. Риск в социальном развитии молодежи. Социально-гуманитарные знания. 2003. № 1. 147-162. 


\title{
References
}

1. Beck, U. (1992). Risk society: towards a new modernity. Sage Publications.

2. Giddens, A. (1991). Fate, risk and security. In A. Giddens (Ed.), Modernity and self-identity: self and society in the Late Modern Age (pp.109-143). Polity Press.

3. Luhmann, N. (1991). Der Begriff Risiko. In N. Luhmann (Ed.). Soziologie des Risikos (pp.9-40). Walter de Gruyter.

4. Kasperson, J., Kasperson, R., Pidgeon, N., \& Slovic, P. (2003). The Social amplification of risk: assessing fifteen years of research and theory. In N. Pidgeon, R. Kasperson, P. Slovic (Eds.), The social amplification of risk (pp.13-46). Cambridge University Press.

5. Slovic, P. (2000). Introduction and overview. In P. Slovic (Ed.), The perception of risk (pp.21-37). Earthscan Publications Ltd.

6. Renn O. (1998). Three decades of risk research: accomplishments and new challenges. Journal of Risk Research, 1 (1), 49-71.

7. Ukraynskaya, O.A. (2012). Ryskolohyya: sotsyal'no-fylosofskyy podkhod k yssledovanyyu "obshchestva ryskov" [Risk science: social and philosophical approach to "risk society" research]. The Journal of V.N. Karazin Kharkiv National University. Series: Theory of Culture and Philosophy of Science, 47, 42-47. [in Russian].

8. Nikitin, S., \& Feofanov, K. (1992). Sotsiologicheskaya teoriya riska: v poiskakh predmeta [Sociological theory of risk: in search of a subject]. Sociological Studies, 10, 120-127. [in Russian].

9. Yanitskiy, O.N. (2003). Sotsiologiya riska [Sociology of risk]. LVS. [in Russian].

10.Williams C., Chuprov V., Zubok J. (2003). Youth, risk and russian modernity. Ashgate.

11.Zubok, Yu., \& Chuprov, V. (2020). Zhiznennyye strategii molodezhi: realizatsiya ozhidaniy i sotsial'nyye nastroyeniya [Youth life strategies: implementation of expectations and social moods]. Monitoring of public opinion: economic and social changes, $3,13-41$. [in Russian].

12. Woodman, D., \& Wyn, J. (2015). Youth and generation: rethinking change and inequality in the lives of young people. Sage.

13.Bartosh O. (2021). Social risks for the youth in the dynamics of Ukrainian society / In N.Varha, B.Hvozdetska (Eds.), Challenges and opportunities of the modern risk society: socio-cultural, economic and legal aspects (pp.77-93). Oktan Print.

14.Chuprov, V.I., Zubok Yu.A., \& Williams, C. (2003). Molodezh v obshchestve riska [Youth in the risk society]. Nauka. [in Russian].

15.Zubok, Yu.A. (2003). Risk v sotsial'nom razvitii molodezhi [Risk in the social development of young people]. Sotsial'nogumanitarnye znaniya, 1, 147-162. [in Russian]

Стаття надійшла до редакції 15.10 .2021 р. Стаття прийнята до друку 20.10.2021 р.

\author{
Бартош Олена Павлівна \\ кандидат педагогічних наук, доцент \\ кафедра соціології та соціальної роботи \\ ДВНЗ «Ужгородський національний університет», м.Ужгород, Україна
}

\section{ФАКТОРИ РИЗИКУ В МОЛОДІЖНОМУ СЕРЕДОВИЩІ}

Анотація. Формування сучасної молоді відбувається в період суспільно-політичних перетворень, що безпосередньо впливає на життєві орієнтації молоді, іії поведінку, соціально-економічне становище. Такі умови сприяють поширенню ризиків пов'язаних із загрозою здоров'ю та життю, з невизначеністю життєвого старту та самореалізацією, ціннісно-нормативною невизначеністю. Метою даної статті є дослідження підходів до визначення факторів ризику, що впливають на молодіжне середовище. Методи дослідження: аналіз і синтез наукової літератури (для з'ясування ключових понять дослідження), систематизація (з метою виявлення наявних наукових підходів до вирішення означеної проблеми), теоретичне узагальнення (для формулювання підсумкових положень та висновків). Характерною для більшої частини молоді $є$ проблема життєвого старту, яка чинить негативний вплив на трудову кар'єру молодих людей, їх сімейне життя і спосіб життя та робить молодь матеріально залежними від батьків. Неабиякий вплив на розвиток суспільства ризику зробила глобалізація. В умовах глобалізації руйнуються традиційні соціальні зв'язки; молодь звільняється від традиційних обмежень, але в той же час позбавляється почуття надійності, стабільності, впевненості в майбутньому і відчуває почуття тривожності і страху перед необхідністю вибору. Тому державній політиці варто враховувати всі чинники, що роблять негативний вплив на молодіжне середовище і сприяти мінімізації прояву ризиків та формувати «соціально здорову» молодь.

Ключові слова: фактори; ризик; соціальна інтеграція; студентська молодь. 